\title{
ART (OUT) OF SEPARATION Aesthetics Around the Wall
}

\section{A B S T R A C T}

A wall is an indispensable architectural element, separating and at the same time also unifying, creating sides, divisions and the possibility of breaking through. What aesthetic potentials and qualities can we find around the wall? Sometimes we concentrate more on what the wall encompasses, but we can put really the wall itself in the focus, for example when examining it in its ruined state: when we can even walk literally around the alonestanding sculptural object, or when interpreting it as being the subject and medium of sculptural interventions. In this paper, with the help of some artworks I would like to examine the role, appearance and "usage" of wall and to show some noteworthy examples where architects and artists were inspired to find new interpretations of this classical architectural element. 
"The unity of the wall dissolves into the plurality of bricks."

(Robert Ginsberg)

We usually think of the wall as an indispensable element and reflect less often on the question of its exact function. What is its most basic task? We could point out "separation" as its primary function. A division between here and there, between this side and the one over the wall, between us and them. This separation then automatically selects a group, the ones on the one side of the wall and offers them a different status than to the other group on the other side. Thus it will be kind of a defense too - separating ourselves inside to get saved from those who are outside, or isolating them inside in order to not get mixed with us who are outside. If we are on the "other side", seeing from there it may look that we are left out, or we are closed in. Hence there is no automatically positive and negative side of the wall - neither here nor there, neither in nor out, is unquestionably favorable or unfavorable. Moreover, this status and especially the change of the status can even have inspiring intersections: it is enough to think of the famous opening of Alfred Döblin's novel titled "Berlin, Alexanderplatz". At the beginning of the story the protagonist Franz Bieberkopf gets released from the Tegel Prison with his strong conviction that he wants to start a new life. His failure is anticipated by the author in a short summary note before the first chapter already, but we might feel it even stronger in the antinomy pictured in the first chapter: he is free, standing in front of the prison gate, already outside the walls that were - even some hours before - closing him in and separating him from both society and the free life. And how does Döblin summarize the coming events and the beginning of his newly regained freedom at this starting moment of the novel? With the shortest possible affirmation: "The punishment begins" . It is not a beautiful life that begins, and the punishment ends only in the terms that his stay in jail is over, but the new life, outside the prison punishment will turn to be the (real) punishment.

The questions on the function of the wall becomes more complex if we are not sure or even cannot be sure of the reliability and of the efficiency of the separating and unifying force of it. This insecurity can be imagined through the rethinking of Constantine Cavafy's well-known poem "Waiting for the Barbarians". In the poem a whole city - including its average inhabitants as well as the leaders - is paralyzed with the fear of the coming barbarians. They shall arrive today - from outside our well-known natural context -, taking (in their "barbarian" way) control of the well-established ("civilized") city. And what happens at the end of the day? 
"Why this sudden restlessness, this confusion?

(How serious people's faces have become.)

Why are the streets and squares emptying so rapidly,

everyone going home so lost in thought?

Because night has fallen and the barbarians have not come.

And some who have just returned from the border say

there are no barbarians any longer.

And now, what's going to happen to us without barbarians?

They were, those people, a kind of solution."”

Cavafy precisely expresses this extremely ambiguous concern. The fear of the enemy coming from the outside blocks everyday life, and the block seems to be resolvable only if the catastrophe really happens and arrives - in the "form" of barbarians. As Matthew Gumpert argued: "It has been the fate of the West for most of its long history to be consumed in the act of waiting. Like the jaded citizens of Constantine Cavafy's, "Waiting for the Barbarians» we always suspected the barbarians were at the gate. It had served our purposes to know they were out there. Indeed, we had looked forward to their coming, not just with a sense of dread, but with something approaching relief. (Blanchot: "The disaster takes care of everything.») The order of our lives, like those of Cavafy's generic polis, had been founded entirely on teleological and, indeed, eschatological principles. "4 In this case then, when they do not arrive, the un-arrival of the catastrophe will be the real catastrophe, since the city's inhabitants have to face too difficult - if not directly unsolvable - problems. One of these problems that the poem still explicitly tells: the typical question of what to do next? What will be, what can be the other solution if the one, undesired but expected, unpleasant but seemingly without alternatives is not valid anymore? What if we are left without solution?

The other problem is not expressed in the poem, however, implicitly it is also there, especially in the inserted parentheses: ("How serious people's faces have become.") - that is in parentheses also in the original Greek version of the poem. From this line we can rethink and think the poem further, and continue to raise other questions. What if the barbarians are not coming because they are already here? They are not to arrive, but have already arrived? The wall, our city, our unified division then leaks, so that they could have already penetrated? Can they really be among us? Can they be any of us? And from here, just one small step more to the most frightening question: are we perhaps 
the barbarians? We took for granted that the wall not only unified us, but also defended us from our (outside) enemy. The insecurity in the strength of the wall (may it be leaking...?) soon turns to be insecurity in ourselves, the worry of the physical enemy will become an auto-referential existential fear. In such case, we cannot be sure what is better: reinforcing the wall or destroying it? Constructing or deconstructing? How can we save ourselves, our city and culture the best?

Also, from the direction of these questions we can interpret an inspiring work of Ayşe Erkmen, presented at the 13th Istanbul Biennial in the autumn 2013. The work, titled "bangbangbang" consisted of a crane, that she placed in front of the building that contained a large part of the works exhibited at the biennale. The crane held a huge ball, just like the ones used for destroying buildings and walls - with the difference that in this case the ball was not made of rockhard metal, but of light plastic. Not only the regular moving of the crane, but even a slighter wind made it swing towards the wall of the building, naturally, without really harming it, being the ball made of a soft material. The work is at the same time worrisome and ironic: referring to the strong potential we have with our tools of quick destruction, but just at the same moment disabling the power to destroy by replacing the ball with a harmless one. However, the constant oscillation of the object unpleasantly reminds us of the question that we inevitably have to face: how to respond to the current situation? What to do with our insecurity? What is our new strategy of defense? Keeping in mind the thoughts that were inspired by reading Cavafy's poem, we can wonder what is the role and potential of destroying if we are uncertain of our own status: are the barbarians among us? Or, are we the barbarians? How to defend the culture that we are so proud of and that gives us the secure and comfortable feeling of supremacy over the barbarians, if we, too, might be the ones whom we wanted

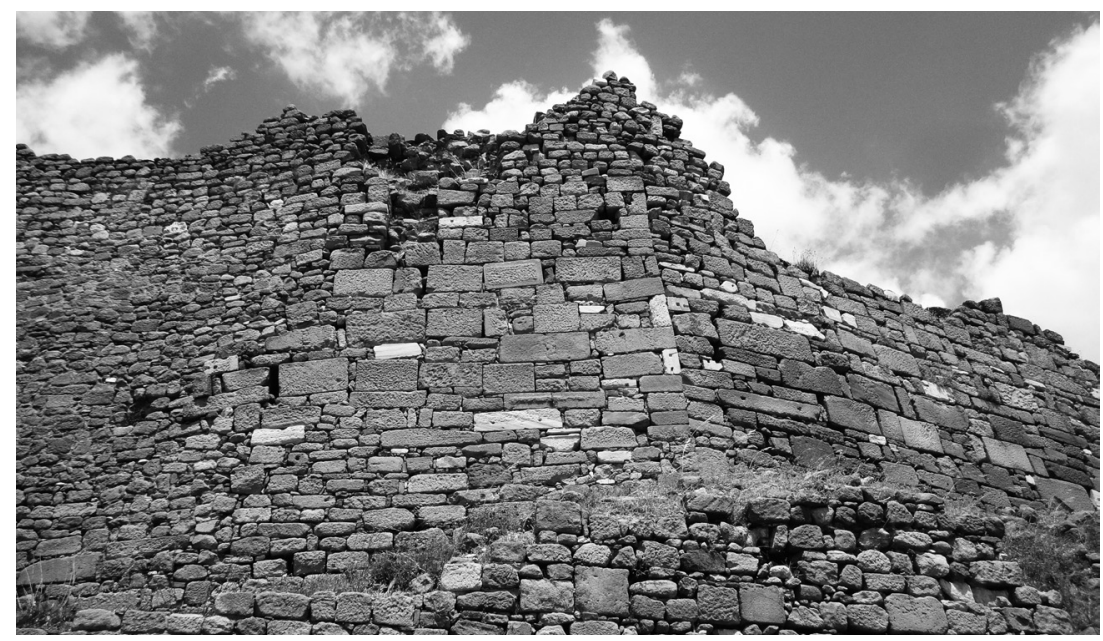


to distinguish ourselves from exactly through the power of civilization? In this case, shall we then erect new walls, or destroy the previous ones? Is the continuous and ever-growing separation the right expression of culture? Or, is it better to destroy the separation? And what if the destroying is the new barbarism? Also, for the meditation on these questions was it a good idea to display Ayşe Erkmen's work right next to the entrance of the main building of the biennial - the event whose title, nota bene, in 2013 was the question: "Mom, am I barbarian"? The work thus has a real actuality too, referring to the constant change of the city of Istanbul, to the continuous destroying and new construction, in the area of the port too, where the biennial took place. But we shall not limit our interpretation to this actuality. As Danae Mossman and Sarah Hopkinson wrote in the Guide to the event: "Erkmen renegotiates the relationship between industrial objects and processes of sculptural production, and reveals the relationship between objects and the viewer as something much more intimate, complex, subjective, and variable. She disestablishes the fixed narratives of sculpture and its legacies rather than drawing on the more abstract relationship between form and experience as subject matter. Often visitors are, quite literally, inside of the work, thinking or feeling their way out. "5 While observing this work, we metaphorically wonder about the next step of our way out from these concerns, while the ball regularly hits the wall as audio-visual sign of a mega-metronome, reminding us of the inevitability of making a decision.

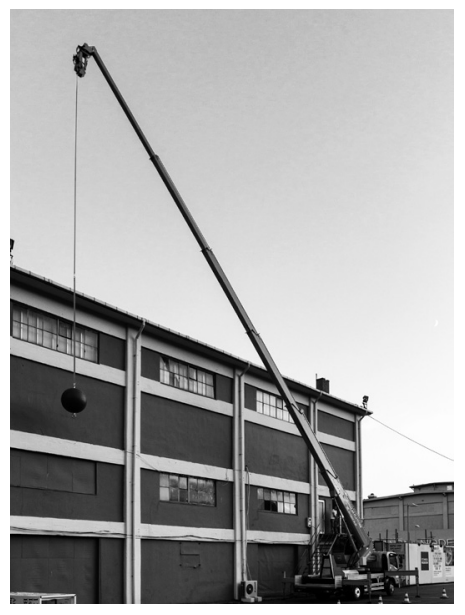

Figure 2. Ayșe Erkmen: bangbangbang, 2013 A crane and a buoy, crane approx. $20 \mathrm{~m}$, buoy diameter $85 \mathrm{~cm}$. Courtesy of Galerie Barbara Weiss, Berlin and Galeri Mana, Istanbul. Photo: Servet Dilber, 13th Istanbul Biennial, 2013 
Without the signs of the "metronome" we can observe the effects of the passing of time at ruined walls - at built divisions that were destroyed "naturally". The wall may easily lose its function if there is no more danger "outside" of it, or if those who built it to defend themselves are not inside anymore. While losing the function and task and especially without the structural and aesthetic upkeep the wall starts to lose its elements too. The ruins of a wall is then deprived of any kind of practical function that we can attribute to an existing wall: not separating territories, not bearing any load and not even leading anywhere as part of a corridor. On the other hand, it may gain an inspiring new aesthetic quality: being the subject of Nature's involuntary, uncontrolled and uncontrollable shaping activity, it can become an alone-standing sculptural object. Not an endless, circular and closed entity, not an organic part of a building, just a large-size - and normally rather long... - sculpture. Natural forces then start to work on the wall, slowly destroying it, taking elements away and eliminating its original form, modifying its lines, height and surface. The passing of time is shown in the picturesque appearance of the wall-ruin, in the result of the "sculptural" activity of Nature.

What earlier did not seem to be possible, i.e. to separate the wall, an integral part, from the entire building, has now happened. From the former complex the wall is separated - and at the same time it does not separate anything anymore. Since the building's earlier integral part becomes a pure sculptural object we can also say that the wall thus becomes the monument of the former building. A part refers to the whole, a remnant, reminding us of the previous and complete entity. A real monument it will be both in the sense of an object of memory that reminds us of the original complex and in the sense of a monumental sculptural work that we can walk around, observe and aesthetically enjoy. While it is an
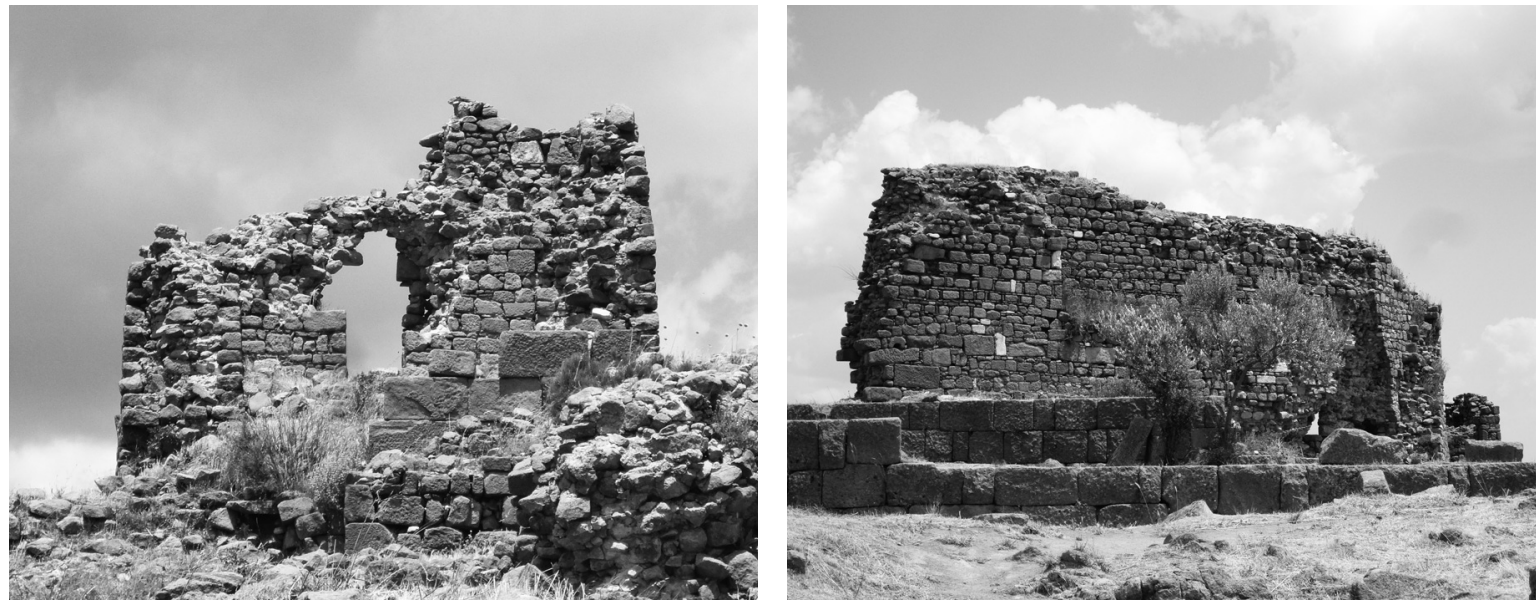

Figure 3-4. Ruins of the Antique city of Pergamon. Photo: Zoltán Somhegyi, 2013 
entire wall, its two-dimensionality dominates: encountering it we focus more on its length and its height. But at the time of its ruined state, during the decades or centuries while it is being dilapidated, its three-dimensional character becomes more and more significant. The former $2 \mathrm{D}$ building element thus will be a 3D object - we can walk around it, having the earlier separating wall in the center of our perambulation, without facing obstacles when constantly changing the side we are on. And, as the decomposition continues, the wall gets lower and lower, enabling us to come to the other side simply over the ex-wall. Earlier it was possible only through the controlled openings of the wall - gates and doors. As Georg Simmel formulated it on a philosophical level, with relationship of inner and outer space: "The human being who first erected a hut, like the first road-builder, revealed the specifically human capacity over against nature, insofar as he or she cut a portion out of the continuity and infinity of space and arranged this into a particular unity in accordance with a single meaning. A piece of space was thereby brought together and separated from the whole remaining world. By virtue of the fact that the door forms, as it were, a linkage between the space of human beings and everything that remains outside it, it transcends the separation between the inner and the outer."

But with the natural decomposition of the wall, this getting over, getting out or getting on the other side is now easy and open to anybody, from either side of the wall. With the natural lowering of the wall its "seriousness" also lowers. A high wall is effectively impeding, but a low wall is just the contrary: tempting - even though the inability of resisting this temptation can have opposite consequences if the wall is low because still under construction or under deconstruction. Overcoming a low wall in deconstruction is fun. But overcoming a low wall still in construction can be a dangerous or even

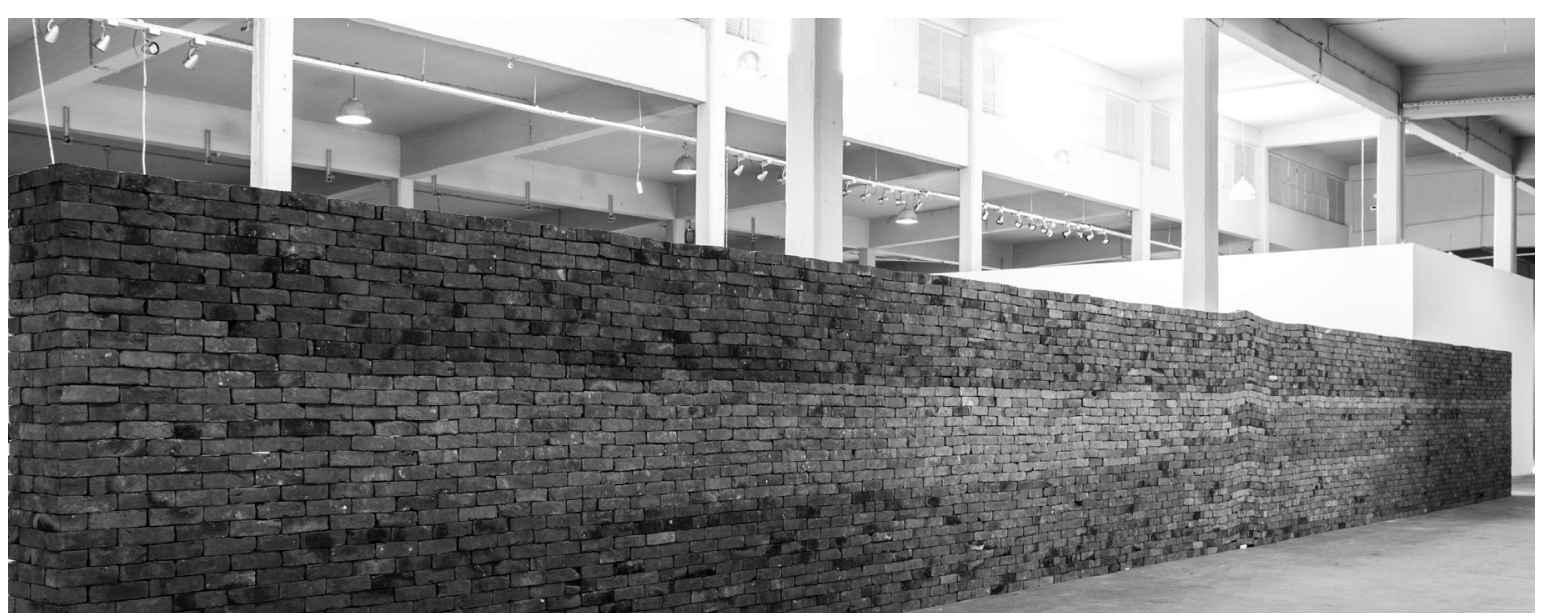

Figure 5. Jorge Méndez Blake: The Castle (El Castillo), 2007

Bricks, book, 170x1500x40cm. Courtesy La Collección Jumex (Ecatepec, Mexico). Photo: Servet Dilber, 13th Istanbul Biennial, 2013 
deadly sin. According to Livy, this led to the death of Remus, as during their conflict: "...Remus contemptuously jumped over the newly raised walls and was forthwith killed by the enraged Romulus, who exclaimed, "So shall it be henceforth with everyone who leaps over my walls.»" We can see a similar trespassing of the wall still in construction in the iconic photograph of Peter Leibing, depicting Conrad Schumann jumping over the barbed wire fence - the later Berlin Wall - in 1961. In these cases from the two extremes of history, (mythologically old and recent) the ignoring of the divisory function of the wall - even if a low wall - is a real transgression. But when the wall loses its function, and gets ruined, we just get across it for fun, without obligations, only for our historical curiosity and for the aesthetic pleasure of observing from all sides the "sculpture", picturesquely shaped by Nature. However, it is definitely ironic, even if perhaps involuntarily ironic when the ruined wall that now offers the possibility of being walked around, and that becomes the object of our attention from any viewpoint - gets separated from us by a thin metal fence, in order to protect the archaeological ruin from further ruination, caused by the human touch, jump and walk over it...

In the example above, Nature destroyed the wall and this resulted in the added aesthetic value. But walls may have new aesthetic value even if they are not entirely destroyed, and sometimes no real harm is needed at all: an illusionistic opening can negate the wall, thus creating an inspiring and aesthetically fertile tension between the real existence of the wall and the questioning its necessity. Already from the Antique times we see examples of trompe l'oeil openings that play at the intersection of the massive structure and fine surface of the wall. Where a wall must be for static or divisory function, but space - the illusion of space - is desired, then a painted opening of the wall can be really pleasant.

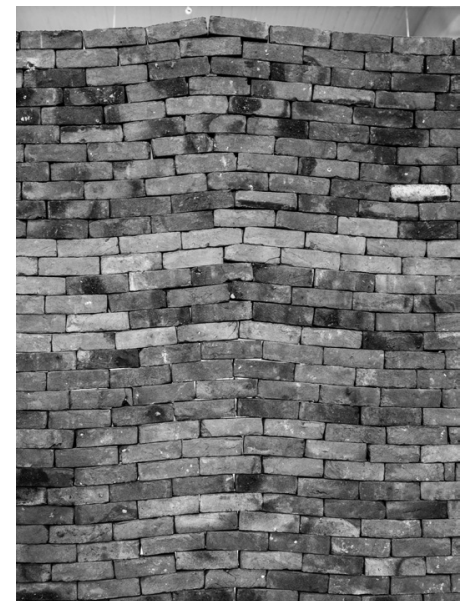


Apart from the well-known and classical examples - The Villa Boscoreale with painted "views" or cityscapes, or Mantegna's Ceiling Oculus in the Palazzo Ducale of Mantova - we can also mention a particular representation, that curiously synthetizes the illusion of opening and Nature's aforementioned powerful work: at the so-called "Ruin Room" in the Pommersfelden Castle in Bavaria, Giovanni Francesco Marchini painted all the walls full of ruins. But not with conventional representations of ruins - he converted the ceiling and walls of the room in a refined and illusionistic way into the vision of a "real time" destroying, as if they were to collapse right at that moment. The visitor thus enters in the middle of a sudden natural catastrophe. As Paul Zucker observed, here "The baroque love of the sensation and of extraordinary events is combined with the romantic preoccupation with arousing reflections about the transiency of human life and creations." In these examples walls are needed, but made either invisible, or, with a Baroque pictorial joke, not simply their necessity and endurance are questioned, but also their existence is negated. Yet walls were not intentionally and physically destroyed for opening up possibilities.

However, we can mention some examples where the artist and/or architect goes even further and where the wall is really harmed by deliberate human activity: when the primary function of the wall gets secondary, and this basic structural element becomes the medium of sculptural intervention. Gordon Matta-Clark - originally trained as an architect - for example cut out parts and forms from existing and intact buildings, intentionally shaping the wall with void, just like Nature shapes the remains of an unused building left unarmed for protection against Nature's power. The edge between architecture and sculpture blurred already in his 1974 project titled "Splitting", when he cut through a house from the 1930s in New Jersey, sinking one part of the original building so that a tiny gap could open in the middle - a gap that of course was getting wider towards the top of the house. Moreover, he cut and exhibited the four top corners of the building as sculptures in a gallery, with the not surprising title: "Four corners". Next year, within the framework of the Paris Biennale he wanted to split the newly constructed Centre Pompidou..., and when his request was rejected, a 17th century apartment building was offered to him as an object of his interaction - a building that was planned to be demolished anyway, to give space around the new museum. In this project, titled "Conical Intersect" a conical void was cut in the house. The architect's sculptural intervention here resulted in a pictorial gesture in and/or through the surface of the wall. Overcoming the dialectics of inside and outside was tried again in his 1977 project "Office Baroque", where he sawed out huge circular forms from an office building in Antwerp. As he 
affirmed: "Light enters places it otherwise couldn't. Spaces are available to move through that were previously inaccessible." 9 The walls are thus partially destroyed to open up new relationships between light and space, inside and outside, void and volume.

In another example the wall's further characteristic gets in the focus: Anish Kapoor shows an ignored "side" of the wall, its third dimensionality through the depth of its volume. It will again become "sculptural", but this sculptural here does not mean that it will be a " real sculpture", like the final result of the left-alone wall that Nature shapes into a perambulatable 3D item, or the cutout corners of the New Jersey house in Gordon Matta-Clark's project. Instead, Anish Kapoor shows the third dimension that the wall already contained in it and that we normally do not consider, concentrating only on its height and length. Anish Kapoor's intervention investigates the basic sculptural potential - the third dimension, i.e. the volume - when emphasizing the depth of the wall. He often cuts huge cracks, painting the inner part with vivid colors, or carves perfectly designed semicircular holes into the wall, that - also due to the fine painting inside it - physically attracts the viewer to immerse in the profound depths of the "opened" wall. Hence the wall is both the medium and the analyzed subject of the work - and the result, the final appearance of the artwork then reflects the way it was created. This auto-referential interaction will open the new dimension, thus showing the depth of the volume the wall incorporates.

Partial breaking of the wall, investigation of its depth and materiality leads to the complete demolishing of it - or, at least to the examination of the possibilities of bringing it down. Overcoming the wall needs the understanding of its "depth" and also of the questioning of the necessity of separation itself. We can never be sure if we are on the right side of the wall and if there is a right side, or - to continue the metaphor - if there is a wall at all? Similarly, we always seem to find ourselves at a side of a wall, but can never be sure if the wall itself is necessary and divides us necessarily? Whether we are really separated from something and from each other, if there really is an impeding obstacle, and whether it really has to be there, or it is just a defeatable physical matter? In fact, this is what Jorge Méndez Blake highlighted in his piece, presented at the same 13th Istanbul Biennial where also Ayşe Erkmen's ball on the crane hit the building. Blake's installation consisted of a long and strong-looking wall that had in the middle a significant imperfection, a starting crack, a strange brake in the seemingly massive pattern of bricks, caused by the insertion of an extra item in the lowest row of bricks: a book, a copy of Kafka's novel "The Castle" heightened the first row. The interpretation of the installation is quite 
open, the work can refer both to the inaccessibility of complete knowledge just like in Kafka's book the protagonist K. does not understand his situation - since we cannot take the book out of the construction, and on the other side it can also refer to the power of thought. In this way, even the strongest wall that looks as an extremely obstructive opposition can be broken through and critical thinking can make cracks to open up towards complete freedom. 
Cavafy, Constantine. Waiting for the Barbarians. Trans. Edmund Keeley and Philip Sherrad. http://www.cavafy.com/poems/content.asp?id=119\&cat=1; last accessed on 30 December 2013

Döblin, Alfred. Berlin, Alexanderplatz. Trans. Eugene Jolas. London: Continuum, 2007. (orig.:1929)

Ginsberg, Robert. The Aesthetics of Ruins. Amsterdam-New York: Rodopi, 2004.

Gumpert, Matthew. The End of Meaning. Studies in Catastrophe. Newcastle upon Tyne: Cambridge Scholars Publishing, 2012.

Guide to the $13^{\text {th }}$ Istanbul Biennial. ed. Liz Erçevik Amado, Istanbul: Istanbul Foundation for Culture and Arts - Yapı Kredı Publications, 2013.

Livius, Titus. The History of Rome. Ed. Ernest Rhys. Trans. Rev. Canon Roberts, J. M. London: Dent and Sons, 1905.

Simmel, Georg. "Bridge and Door," In Rethinking Architecture. A Reader in Cultural Theory, ed. Neil Leach. London: Routledge, 1997.

Ursprung, Philip. "Living Archaeology: Gordon Matta-Clark and 1970s New York," In Die Moderne Als Ruine. Eine Archäologie der Gegenwart-Modernism as a Ruin. An Archaeology of the Present, ed. Sabine Folie, trans. Lisa Rosenblatt, 154-159. Nürnberg: Verlag für Moderne Kunst, 2010.

Zucker, Paul. Fascination of Decay: Ruin, Relic, Symbol, Ornament. Ridgewood: N. J. Gregg Press, 1968. 


\section{GRAD KAO DRUŠTVENA SKULPTURA}

\section{Jale Erzen}

Argumenti u ovom radu pokušavaju da pokažu da je grad u osnovi društveni prostor i da su pre njegove fiksiarne materije u formi arhitekture i urbanih struktura ipak to ljudi koji izgrađuju bitan karakter i prisustvo grada. Ideja društeve skulpture je uzeta kao živopisna metafora koja se poziva na prethodni rad i ideje Jozefa Bojsa. Bojs je tvrdio da su događaji i postupci ljudi u gradu društvene skulpture i to je ilustrovao u svom čuvenom performansu čišćenja ulica sa svojim studentima. Grad pripada ljudima i gradovi su odgovornost svojih stanovnika. Zalažući se za to, ovaj rad se isto tako poziva na GEZI događaje u Istanbulu. Ovi argumenti vode do zaključka da će vitalnija i značajnija umetnost u budućnosti morati da se odnosi na urbani kontekst više nego na bilo šta drugo.

KLJUČNE REČI: DRUŠTVENA SKULPTURA, GRAD, AKTIVIZAM, DRUŠTVENO TELO, NOVA UMETNOST

\section{UMETNOST (IZ) ODVAJANJA: ESTETIKA OKO ZIDA}

\section{Zoltán Somhegyi}

Zid je neophodan arhitektonski element, koja odvaja a u isto vreme ujedinjuje, stvarajući strane, podele i mogućnost proboja. Koje estetske potencijale i kvalitete možemo da nađemo oko zida? Ponekad se skoncentrišemo više na ono što zid obuhvata, ali možemo stvarno sam zid da stavimo u fokus, na primer, prilikom ispitivanja zida u ruševnom stanju: kada čak bukvalno možemo da hodamo oko samostojećeg vajarskog predmeta, ili kada ga tumačimo kao predmet i medijum vajarskih intervencija. U ovom radu, uz pomoć nekih umetničkih dela želeo bih da ispitam ulogu, pojavnost i „korišćenje“ zida, i da pokažem neke zapažene primere gde su arhitekte i umetnici bili inspirisani da pronađu nova tumačenja ovog klasičnog arhitektonskog elementa.

KLJUČNE REČI: ZID, RUŠEVINE, PRIRODA, VAJARSKA INTERVENCIJA, SAVREMENA UMETNOST

\section{“INTERNACIONALNI" STIL ARCHITEKTURE U JAPANU TRIDESETIH GODINA: VERNAKULARNOST I MONUMENTALNOST}

\section{Daiki Amanai}

Nakon ovladavanja Zapadnom arhitekturom hiljadu devetso desetih, japanske vrhunske arhitekte su bile suočene sa dva problema: kreiranjem sopstvenog stila koji se bazira na japanskim tradicijama i klimatskim ili seizmološkim uslovima i obrazovanjem običnih ljudi da stvore ukus za arhitekturu izvan površne imitacije onog sa Zapada. Pre svega, jedan od elite i prvobitni ekspresionista arhitekta Horiguči Sutemi je diskutovao o ne-urban-nosti koja povezuje japanske čajane i holandske seoske kuće. To je izrazio putem svog modernističkog tiumačenja funkcije, svog iskustva u Holandiji i reakcijom protiv administrativnih stavova o gradu i arhitekturi iz dvadesetih godina. Drugo, uprksos svom ranijem udaljenom stanovištu o monumentalnosti, njegov zahtev za vrhunskim izražavnaje nekih projektovanih spomenika širom sveta je revitaliziralo njegovu sopstvenu sklonost. Naizgled njegovi stavovi prema monumentalnosti su se promenili i osobina spomenika koji su odavali počast žrtvama rata ili podizala nacionalni ugled bila je suprotstavljena "internacionalnoj" odlici moderne arhitekture. Iako ove poente mogu da prikriju njegovu doslednost, možemo da pronađemo njegov kontinuirani dualizam: jedno je funkcionalnost koja je prevladala nad arhitektonskim diskursom tog doba i Horiguči je isto tako smatrao a drugo je njegov izraz koji je lokalnoj vernikularnoj praksi obezbedio poziciju u svetu. Ovi argumenti nam omogućavaju da među moderne arhitekte iz tog doba ubacimo potencijalno razumevanje ali u novom svetlu. 